BIP: Jurnal Bahasa Indonesia Prima Vol. 3, No. 2, 2021, September 2021, PP.

\title{
LASMI DAN GOTHIC FEMINISM DIANA LONG HOEVELER
}

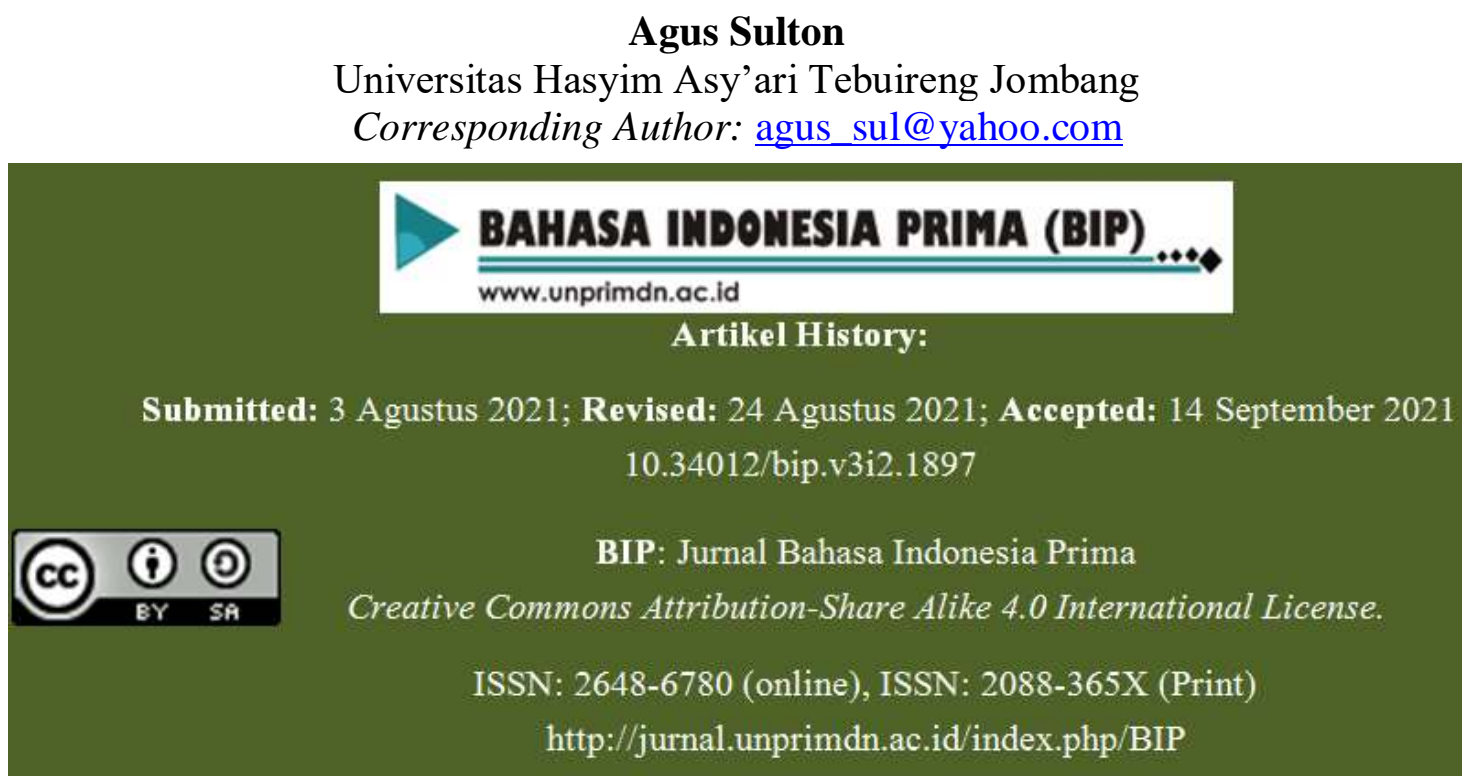

Abstrak-Konsep gothic feminisme berbeda dengan pengertian feminisme pada umumnya. Gothic feminisme merupakan konsep feminis yang lahir dari perempuan korban terhadap diskriminasi dan dominasi untuk memulai meluapkan pembalasan. Penelitian ini bertujuan untuk mengungkapkan kandungan teks gothic feminism berdasar teori Diana Long Hoeveleryang terdapat dalam novel Lasmi karya Falen dan Ara. Hasil penelitian ini menemukan, bahwa tokoh Lasmi merupakan simbol atas perempuan korban akibat diskriminasi budaya dan sosial tentang identitas wanita. Hadirnya tokoh Lasmi bagian dari upaya penulis untuk mengajikan pengetahuan sekaligus revisi sistem budaya dan sosial yang berkembang di masyarakat.

Kata kunci: lasmi, diskriminasi, gothic feminism, revisi sistem

Abstract-The concept of gothic feminism is different from the understanding of feminism in general. Gothic feminism is a feminist concept born to a victim woman against discrimination and domination to start ventilation. This study aims to reveal the content of Gothic Feminism's text based on Diana Long Houler's theory contained in the Lasmi novel Falen and Ara. The results of this study found that Lasmi figures were symbols of women victims due to cultural and social discrimination about female identity. The presence of Lasmi figures part of the author's efforts to study knowledge and revise cultural and social systems that develop in the community.

Keywords: lasmi, discrimination, gothic feminism, system revisions.

\section{A. Pendahuluan}

Genre sastra mulai bermunculan, berkembang, dan memperkuat ideologinya ketika orde baru berakhir, dan memasuki masa reformasi. Dalam masa tersebut, sastra tidak lagi konsisten terlibat dengan struktur yang membelenggu seperti masamasa pra kemerdekaan, orde lama, dan orde baru. Kalau sastra sebelum reformasi cenderung banyak menceritakan orangorang yang kalah dan mencoba untuk mencurahkan kekalahannya dengan 
propaganda, agitasi, sindiran, kritik, dan sebagainya. Namun pasca orde baru mulai tumbuh genre aroma post, media teknologi, dan kebebasan.

Sastra tidak semata-mata memiliki arti "bermakna dan menghibur", tetapi ada kepentingan-kepentingan suara kelompok ataupun suara yang menjadi bagian dari gerakan simbolik, dan media sastra bagian dari alat untuk memperkuat cara pandang, misalnya genre sastra horor. Genre sastra ini mempunyai sub genre yang beragam, seperti: (a) genre occult adalah genre cerita yang fokus mengungkapkan tema tradisi masyarakat lokal dengan unsur mistis; (b) genre zombie adalah cerita yang mengambil tema-tema mayat yang hidup kembali kemudian menghantui masyarakat atau seseorang yang pernah menyakitinya; (c) genre boddy horor adalah cerita yang menyajikan unsur kekerasan secara sadis pada tubuh manusia; (d) genre found footage adalah cerita horor yang disampaikan oleh sudut pandang orang pertama atas peristiwa yang sudah terjadi; (e) genre slasher adalah cerita yang menyajikan kekuatan suatu benda dan bisa membantu tokoh antagonis untuk memburu lawan-lawannya. Benda itu bisa jadi berupa pedang, pisau, batu, gergaji, dan sebagainya.

Dalam sejarah tradisi kritik teks, genre sastra tersebut dikenal dengan gotic feminism. Setelah pasca runtuhnya Orde baru, di Indonesia genre sastra gothic berkembang sangat pesat. Fenomena produksi budaya simbolik ini kemungkinan respon krisis demokrasi yang telah lama membelenggu ataupun penerapan kebijakan neoliberal yang semakin merugikan.

Gothic feminism pada awalnya mengangkat kisah misteri dan ketakutan yang melampaui akal sehat (mistik), logis, dan tatanan positif di dunia. Kemudian kisah tersebut dikembangkan pada karakter-karakter elitis di sebuah kastil mewah, mengerikan, dan kabibalistik (Hoeveler, 1998; Ledoux, 2017). Hadirnya perempuan dengan suasana yang berbeda ini awalnya muncul pada abad ke-18 di Inggris atas tulisan Mary Wollstonecraft berjudul A Vindication of the Rights of Women, kemudian disusul anaknya sebagai penulis gothic feminis paling terkenal, yakni Mary Shelley, penulis Frankenstein.

Istilah gothic berasal dari orang-orang goth yang identik dengan kanibalisme dan kekerasan. Kemudian awal abd ke-20, secara sosial makna gothic mengalami pergeseran makna setelah munculnya karya Millennium, Twilight, Game of Thrones, The Walking Dead, Stranger Things, dan sebagainya. Gothic kemudian dikenal masyarakat sebagai monster, zombie, vampir, mutan, hantu, cyborg, dan makhluk gaib lainnya yang hidup berdampingan dengan masyarakat global. Sudah pada tahun 1976, Ellen Moers telah menciptakan istilah gothic feminism untuk merujuk pada penulis perempuan yang mengolah genre ini sebagai ruang subversif untuk menampilkan penindasan sosial dan politik perempuan, pengurungan tubuh mereka, marginalisasi pekerjaan mereka, cerita wanita muda yang terbunuh mengenaskan, dan ketidakmungkinan untuk mengekspresikan kebebasan seksual mereka.

Beberapa kritikus, seperti Brescia, Negroni, Braham, Diez Cobo, CasanovaVizcaíno, dan Ordiz, gothic dilihatnya sebagai genre realisme magis. Namun, gothic feminism lebih akrab disebut sebagai pemberdayaan perempuan, membangun di atas yang jahat, sebagai proses subjektivisasi (Delucia, 2009; 
Hawkins, 2019).Secara lebih luas, gothic feminism merupakan sastra yang beranggapan tentang bangkitnya para perempuan yang selama ini tertindas kemudian muncul sebagai sosok orang yang luar biasa, pada akhirnya menghantui mereka yang sebelumnya berbuat tidak adil. Secara sederhana, gothic feminism bisa disebut sebagai victim feminism atau feminisme korban, artinya orang-orang perempuan yang sebelumnya pernah menjadi korban kererasan, seksual, diskriminasi, dan lain-lain kemudian dia berbalik melakukan perlawanan atas dominasi yang pernah membelenggunya, misalnya novel The Life and Loves of a She-Devil (1995) karya Fay Weldon, Bridget Jones's Diary (1996) karya Helen Fielding, The Magic Toyshop (1996) karya Angela Carter, dan sebagainya.

Di Indonesia, karya sastra bertema gothic feminism cukup banyak, salah satunya novel Lasmi karya Falen dan Ara. Novel tersebut mengisahkan kehidupan Lasmi sebagai seorang sinden yang diidentikkan oleh masyarakat dengan perempuan gundik dan suka menggoda lelaki. Para tetangga juga menuduh, Lasmi adalah perempuan mandul. Padahal apa yang dituduhkan para tetangganya itu tidak terbukti, dan Lasmi merasa dirinya tidak seperti itu. Lasmi menjadi sinden hanya meneruskan perjuangan $\mathrm{Bu}$ Atna yang mendirikan group Eros Bodas.

Fitnahan yang datang dari tetangga bagi Lasmi merupakan diskriminasi terhadap hak-hak perempuan. Tetangga Lasmi menilai, wanita ideal adalah wanita yang bisa melahirkan anak, pandai memasak, dan menjadi pelayan untuk suaminya. Lasmi tidak dapat melawan, dan hanya menerima fitnahan dari tetangganya walaupun batin Lasmi merasa tertekan. Pada suatu ketika, usai pentas group Eros
Bodas Lasmi pulang sendiri lebih dulu karena perutnya merasa sakit. Di tengah perjalanan, Lasmi ditabrak mobil sampai meninggal dunia di tempat kejadian.

Ketidakwajaran kematian Lasmi membuatnya menjadi kuntilanak merah. Lasmi yang dulunya tertindas akibat diskriminasi masyarakat, kini Lasmi yang berwujud kuntilanak merah berbalik menyerang orang-orang yang dulu pernah menyakitinya. Peristiwa Lasmi kalau Hoeveler (1998) memposisikan sebagai etika perempuan dalam ruang teks tokoh yang suci, bahwa identitas tubuh adalah sesuatu yang privat bukan seperti antiheroine feminis gothic yang meletakkan seksualitas secara bebas.

Dalam tradisi sejarah sastra Inggris, Diana Hoeveler (1998) mengamati, bahwa para penulis gothic menulisnya tidak sekadar pada kisah sensasional tentang malam yang gelap dan penuh misteri. Mereka juga mengungkapkan kode-kode baru tentang perilaku perempuan pelayan kaum borjuis, sekaligus memunculkan teks tumbangnya budaya patriarki. Perempuanperempuan hebat itu disebut Hoeveler sebagai pahlawan wanita yang murni.

Hoeveler menilai kode baru itu diistilahkan dengan "feminitas profesional" atau feminisme gothic. Namun, Naomi Wolf (1994) menyebut dengan istilah feminisme korban. Hoeveler pada dasarnya merujuk pemahaman Wolf, bahwa feminisme korban merupakan sikap mempertahankan peran ganda atas lakilaki. Feminisme korban berevolusi dari sistem wacana yang sekarang kita kenal sebagai gothic feminism. Dengan demikian, pemahaman tentang asal-usul gothic ini sangat penting untuk memahami feminisme korban. Pemikiran Hoeveler pada dasarnya membincang tentang 
profesionalisasi gender dalam kaitannya dengan sastra gothic.

Dalam penelitian ini akan sedikit bergeser dengan cara pandang Hoveler yang memposisikan penulis novel sebagai modalitas "feminisme korban" dan karyanya sebagai sumber penting untuk melihat pergeseran itu. Namun, Ara sebagai wanita berdarah Pasundan yang punya perhatian di bidang fashion, menyukai karya visual dan Falen yang tertarik degan kebebasan berfikirnya merupakan potensi yang menarik dalam memposisikan kode-kode perilaku wanita. Pemahaman "feminisme korban" tidak semata-mata penulis dilihat sebagai objek yang dapat jadi pertimbangan mutlak, tetapi bukan "feminisme korban" juga mempunyai perhatian yang sama untuk mengambil bagian dari ide-ide dasar yang diproyeksikan melawan patasan patriarki. Pada dasarnya karya sastra lahir bukan atas dorongan peristiwa diriya, tetapi ide feminis kekaryaan dapat lahir dari lingkungan yang bersifat alamiah maupun terberi.

\section{Diskriminasi Lasmi}

Gambaran diskriminasi terhadap perempuan sudah dilihat Lasmi sejak dia kecil, yakni sosok bibinya yang ditinggalkan Engkus, mantan suaminya. Bi Entin menduga, Engkus meninggalkan dirinya untuk menikah dengan perempuan lain. Lasmi yang orang tuanya pergi merantau tanpa kembali, memaksa dirinya harus tinggal bersama Bi Entin. Bahkan sampai dirinya dinikahkan bibinya, seperti kutipan:

Bi Entin adalah pekerja pemetik teh di kebunnya orang kolonial Belanda. Upah dari memetik tidak cukup untuk menyekolahkan Lasmi, sehingga $\mathrm{Bi}$ Entin berencana akan menikahkan Lasmi di

masa belia (hlm. 14-16).

Karena tradisi sosial yang berkembang di pedesaan, bahwa perempuan usia 12 tahun sudah layak untuk dicarikan jodoh. Lasmi salah satu perempuan yang menjadi korban terhadap tradisi masyarakat. Lasmi pada dasarnya belum ingin menikah tetapi bibinya memaksa untuk menikah dengan Asep, anak juragan tomat.

Pada akhirnya Lasmi menikah dengan Asep, anak dari Pak Jajang dan Bu Atna pada usia 12 tahun. Awal pernikahan, Asep membantu Pak Jajang berjualan tomat sedangkan Lasmi membantu kegiatan rumah tangga bersama $\mathrm{Bu}$ Atna sekaligus di ladang tomat membantu $\mathrm{Bi}$ Entin. Namun, Lasmi juga menyempatkan belajar menyinden dari $\mathrm{Bu}$ Atna, mertuanya. $\mathrm{Bu}$ Atna mempunyai group musik Eros Bodas yang bersanggar di rumahnya. Setelah belajar selama enam bulan, Lasmi diperbolehkan nyinden di pementasan.

Pementasan pertama Lasmi tersebut membuat group Eros Bodas naik dauh. Pementasan yang awalnya sebulan sekali, kini bisa seminggu sekali bahkan lebih. Bahkan tiga tahun gabung dengan Eros Bodas, Lasmi bisa membeli rumah dari hasil nyinden. Rumah yang baru beli dan ditempati Lasmi berdekatan dengan rumah Pak Jajang, hanya berbeda dusun. Tetangga memperlakukan Lasmi kurang baik. Lasmi dituduh dan diwanti-wanti tetangganya untuk tidak bermata keranjang terhadap suami-suami tetangganya. Padahal Lasmi tidak pernah bersikap dan membuat salah pada tetangganya tetapi hantaman fitnah datang bertubi-tubi. Hal ini membuat Lasmi merasa terdiskriminasi atas sikap sosial.

Selain soal fitnahan dari tetangga, Lasmi juga terpikirkan dengan dirinya 
yang belum dikaruniai anak. Padahal sudah lebih dari lima tahun dirinya menikah. Tidak sedikit tetangga yang membicarakan keberadaannya, terutama $\mathrm{Bu}$ Harja, bahkan Lasmi dikata mandul, seperti kutipan:

Setelah fitnah, muncul gunjingan tentang Lasmi yang tidak kunjung hamil karena mandul. Lasmi mencoba selalu tabah dan menutup telinga. Tapi, Lasmi juga punya hati yang bisa terluka (hlm. 111).

Serangan gunjingan tidak hanya menimpa Lasmi, tetapi suara itu juga muncul dari pelanggan dan teman Asep di pasar sayur. Asep dengan tabah menghadapi gunjingan itu, bahkan berulangkali Asep meredam kondisi psikologi Lasmi.

Lasmi pada dasarnya mengalami dua trauma psikologi, yakni diskriminasi karena tradisi nikah muda yang berkembang di masyarakat dan trauma karena fitnah dari tetangganya. Kondisi seperti ini yang membawa Lasmi muncul dendam. Dendam yang lahir dari supranatural di atas yang alami. Dalam tulisan-tulisan Gothic feminism, fantasi bisa mendominasi kenyataan, dan yang aneh di atas yang biasa, dengan satu tujuan autorial yang pasti, yaitu untuk menakutnakuti. Bukan berarti, menjangkau ke kedalaman jiwa dan membersihkannya dengan rasa kasihan dan teror, tetapi untuk mencapai tubuh itu sendiri (Moers, 1977).

\section{Pembelaan Kesetaraan Gender}

Ketika Lasmi pada posisi difitnah karena suka menggoda lelaki lain dan digunjing mandul, sikap keheranan datang dari pembantunya, Pak Salim. Menurutnya, semasa perempuan harus saling menguatkan dengan sesama perempuan, tetapi kondisi sosial berbanding dengan kondisi sosial di kampung Lasmi, seperti kutipan:

Mengapa bisa-bisanya
perempuan lebih jahat kepada
sesamanya? Pikir Salim.
Bukannya saling mendukung
dan mendoakan, malah
menyakiti tanpa alasan yang
jelas. Salim sering juga
mendengar gunjingan-
gunjingan semacam itu ketika
mangkal di pasar (hlm. 107).

Kutipan tersebut menunjukkan, kehadiran tokoh Salim di novel Lasmi merupakan suara simbolik yang disampaikan Falen dan Ara, sebagai penulis. Penderitaan Lasmi sebagai wanita yang terdiskriminasi akibat tekanan sosial merupakan gambaran realistik, bahwa masyarakat di sekeliling kita masih banyak yang kurang perhatian terhadap suara kaumnya. Salim juga menyodorkan amanat, kalau sepatutnya perempuan harus lebih punya perhatian, bukan malah menggunjing atau memfitnah. Tokoh Salim di sini sebagai wujud pemahaman dan pendidikan kepada pembaca kalau lelaki yang sepatutnya adalah menghargai dan memposisikan wanita sebagai sosok yang setara.

Selain Salim, Asep juga mempunyai pandangan yang sama dengannya. Asep memposisikan perempuan sebagai seorang yang tidak hanya terdiam di rumah. Asep sangat menghargai peran perempuan mempunyai derajat yang sama dengan lelaki, seperti kutipan:

"Tidak, Pa. Kalau menikah cuma karena biar ada yang mengurus, lebih baik bayar pembantu. Istri itu bukan babu yang menikah cuma untuk urusan dapur dan kasur." (hm 176). 
Kutipan tersebut menjadi bukti, bahwa cara pandang Asep terhadap perempuan tidak sekedar pada ranah domestik, tetapi perempuan juga bisa ke ranah publik. Perempuan dan lelaki sama-sama saling melengkapi tanpa ada diskriminasi antar pihak.

Selain tokoh Salim dan Asep, penulis juga menampilkan tokoh lainnya yang juga punya perhatian terhadap peran perempuan. Singkatnya, pada suatu malam Lasmi diundang pentas di Balai Kota. Saat usai pentas berlangsung Lasmi dan group Eros Bodas diajak makan-makan bersama para pejabat Balai Kota, ada Koenraad dan Goldewyn. Di waktu makan, Koenraad dengan lancang mengucapkan, bahwa dirinya ingin bersetubuh dengan Lasmi. Perkataannya sangat kasar, dan memaksa Lasmi untuk menjadi gundiknya. Saat keduanya berseteru, Lasmi tiba-tiba ditarik menjauh oleh salah seorang perempuan berkebangsaan Belanda, seperti kutipan:

"Kau baik-baik saja?" tanya wanita Londo itu di depan pintu.

Lasmi sesenggukan. "Saya baik-baik saja, Nyonya."

"Koenraad sedang mabuk, sebaiknya kau dan teman-temanmu cepat pergi dari sini." (hlm. 117).

Melalui kutipan tersebut, sangat jelas terlihat bahwa keberadaan tokoh perempuan Belanda yang membantu pada posisi terhimpit adalah tokoh yang berwujudannya sengaja dimunculkan di dalam novel Falen dan Ara. Peristiwa yang difiksikan merupakan peristiwa yang disengaja untuk mendidik, mencerahkan, ataupun mengajak pembaca untuk bersikan iba dalam suatu konteks sosial. Sastra fiksi hanya pemantik penalaran seseorang untuk bisa dan belajar tentang identitas tubuh sekaligus martabat seorang perempuan.
Dalam paragraf narasi, sudut pandang orang kedua menyampaikan dengan terang, bahwa wanita terhormat adalah wanita yang dapat mempertahankan harkat dan martabat, seperti kutipan:

...Lasmi memiliki hak dan martabat, sekalipun terjebak dalam asumsi miring yang melekat pada pekerjaannya. Sayang sekali pula di zaman itu, persepsi masyarakat mematok nilai seorang wanita berdasarkan pada fungsi reproduksi, yakni wanita yang tidak bisa memiliki anak dianggap sebagai wanita yang tidak utuh (hlm. 118).

Kutipan tersebut menyampaikan pesan, bahwa perempuan tidak semata-mata hanya diukur dari fungsi reproduksi. Namun, secara simbolik penulis novel mengkampanyekan kalau perempuan itu juga mempunyai derajat dan posisi yang sama dengan lelaki. Sehingga reproduksi bukan satu-satunya tolak ukur perempuan menjadi sosok perempuan seutuhnya. Tokoh Lasmi merupakan suara identitas yang ingin dibangun penulis novel. Falen dan Ara ingin mengkronstruk pemahaman kepada masyarakat pembaca kalau suatu pekerjaan yang sangat dekat dengan disorganisasi sosial tidak selamanya sesorang melakukan perbuatan semacam itu.

\section{Kuntilanak Merah dan Gothic Feminism}

Peristiwa gothic feminism merupakan rangkaian proses yang menyertai sebelumnya. Kondisi ini lebih tepat dengan suatu pembalasan dari seorang wanita yang diakibatkan oleh peristiwa terdiskriminasi, dominasi, kekerasan, dan sebagainya sampai akhirnya si korban ini berbalik arah menyerang kembali. 
Menurut Creed (1993), gothic tidak selalu cocok untuk emansipasi wanita, tetapi sangat cocok untuk kemarahan wanita. Creed mengambil kesimpulan kalau gothic feminism sebagai feminitas hina karena menunjukkan situasi yang berlebihan, kekuatan luar biasa, dan tidak terkendali yang malah menggaggu norma patriarki kewanitaan.

Hal ini sama dengan cara pandang Ahmed (2010), bahwa kehadiran wanitawanita itu selalu mengeksplorasi bagaimana proses kemarahan tanpa mempunyai batasan yang sering aneh, semacam feminin mengerikan. Namun, Diana Hoeveler (1998) sangat menghargai keberadaan tokoh-tokoh semacam itu karena ada banyak simbol, teror, dan kodekode yang ingin merewa tawarka. Ekspresi ini wujud dari peringatan atas budaya patriarki yang terus ada dan terjadi di masyarakat. Jadi, gothic feminism merupakan gerakan sosial simbolik atau ide ekstrimis yang hendak ditawarkan oleh sebagian masyarakat yang anti terhadap diskriminasi terhadap perempuan.

Dalam novel Lasmi karya Falen dan Ara peristiwa gothic feminism atau female gothic dimulai saat tetangga mulai berhenti menggunjing Lasmi menyoal isu kemandulannya setelah dirinya 10 tahun berumahtangga. Lasmi mulai hamil, dan masyarakat sedikit malu karena apa yang dituduhkan tetangganya tidak terbukti. Tiga bulan kehamilan, Lasmi merasa bosan di rumah karena tidak bisa beraktivitas seperti biasa. Dadang datang, menawari Lasmi untuk pentas hajatan. Lasmi merasa tergiur ingin mengobati kerinduan di panggung. Lasmi merayu Asep untuk memberikan izin pentas, walaupun Asep tidak berkehendak karena Lasmi baru tiga bulan hamil.
Paksaan Lasmi membuat Asep luluh, dan mengizinkan Lasmi pentas. Usai pentas berlangsung, Lasmi merasa mualmual muntah, akhirnya Lasmi izin pulang sendiri terlebih dulu dengan berjalan kaki. Di tengah perjalanan yang gelap gulita, tiba-tiba ada mobil yang dikendarahi Hendra menabrak tubuh Lasmi sampai mulutnya robek, tangannya patah, dan keluar darah di beberapa tubuhnya.

Tidak berselang lama, Lasmi menghembuskan nafas terakhir di jalan tanpa bantuan siapapun. Setelah menabrak Hendra melarikan diri supaya permasalahannya tidak berbuntut panjang. Kematian Lasmi berubah menjadi hantu kuntilanan merah. Saat di dunia Lasmi tidak berani melawan terhadap orangorang yang pernah menyiksa dan menggunjing dirinya. Setelah menjadi kuntilanak merak, roh Lasmi beraksi membalas semua dendam dan diskriminasi yang pernah menimpanya.

Dendam pertama menyerang Bu Harja yang saat di dunia sering memfitnah karena dirinya mandul. Saat $\mathrm{Bu}$ Harja tidur, tiba-tiba Lasmi masuk ke dalam tubuhnya, seperti kutipan:

Dalam penguasaan Lasmi, pikiran $\mathrm{Bu}$ Harja dipaksa menyaksikan penderitaan Lasmi, akibat gunjingan yang dilakukan wanita itu. Bu Harja juga dibuat melihat gambaran tragedi nahas yang menimpa Lasmi. Lasmi tertawa mendengar teriakan minta ampun dari $\mathrm{Bu}$ Harja...Lasmi hanya membalas perbuatan mereka yang pernah jahat kepada Lasmi! Seumur hidup Lasmi tersiksa, tidak bisa membalas mereka yang jahat kepada Lasmi. Mereka harus 
mendapatkan ganjarannya (hlm.

152-153).

Perlawanan Lasmi merupakan dendam yang selama ini perempuan ideal dilihat $\mathrm{Bu}$ Harja itu harus punya anak. Lasmi sebagai perempuan merasa tertekan, bukannya sesama perempuan saling melindungi atas penderitaan semacam itu, tetapi $\mathrm{Bu}$ Harja malah menggunjing bersama tetangga lain tentang keadaan Lasmi.

Selain Bu Harja, Lasmi juga membalas dendam kepada Koenraad, seorang keturunan Belanda yang pernah memaksa untuk menjadi gundik. Dalam pandangan Koenraad, sinden identik dengan perempuan yang mempunyai derajat seperti wanita-wanita gundik. Oleh sebab itu, waktu pentas di Balai Kota Lasmi pernah dipaksa untuk diajak berhubungan seks. Permintaan itu ditolak Lasmi, berkat bantuan perempuan Belanda yang ada di acara tersebut.

Peristiwa itu membekas dalam diri Lasmi, bahkan sampai trauma berkepanjangan dan menjadi buah bibir para tetangga di kampungnya tentang peristiwa malam itu. Dendam dan amarah itu terus berlanjut ketika Lasmi mati menjadi kuntilanak merah. Pada saat Eros Bodas pentas malam di rumah orang keterunan Belanda, Lasmi diam-diam mengikuti pementasan tanpa kasat mata. Di situ, Lasmi melihat Koenraad yang dulu pernah mengacaukan kejiwaannya. Usai pentas berlansung, Lasmi menarik Koenraad dalam suatu ruangan, kemudian membenturkan kepala dan tubuhnya sampai nyawa melayang.

Pembalasan itu adalah bentuk perlawanan Lasmi atas peristiwa yang pernah mengancam jiwanya akibat diskriminasi cap terhadap sinden. Lasmi merupakan feminisme korban yang pada saatnya akan membalas diskriminasi identitas perempuan. Narasi novel Lasmi karya Falen dan Ara ibarat protes simbolik pada pemahaman masyarakat tentang budaya patriarki. Novel ini membuktikan, bahwa perempuan di balik kelemahannya suatu saat punya kekuatan dan akan menghantui sekaligus membalas dendam atas kondisi yang pernah dialaminya.

\section{Kesimpulan}

Novel Lasmi karya Falen dan Ara merupakankarya sastra di mana tokoh sentralnya adalah seorang wanita muda bernama Lasmi yang sekaligus menjadi korban penganiayaan dan pahlawan wanita pemberani yang dilakukan sebelumnya tidak bisa dilakukan sendiri tanpa menjadi kuntilanak merah. Lasmi menempatkan perjuangan feminisme ekstrimis melawan diskriminasi kulturan dan sosial. Secara lahiriah logika Lasmi tidak memiliki kemampuan untuk melawan atas budaya patriarki. Namun, Falen dan Ara menawarkan kode-kode simbolik untuk menciptakan perlawanan terhadap perempuan korban. Langkah ini berfungsi sebagai pengetahuan sekaligus revisi sistem budaya dan sosial yang berkembang di masyarakat tentang identitas wanita. Apa yang tidak terlihat dan tidak terucapkan merupakan makna cerita, sebuah kebenaran buram yang disusun kembali oleh setiap pembaca dengan caranya sendiri. Walaupun Falen dan Ara melahirkan fiksi bukan sebagai realisme tetapi sebagai fantasi gothictetapi ada kontribsi romantisisme sebuah mitos orisinalitas asli pada karyanya untuk mengetuk hati masyarakat pembaca.

\section{Daftar Pustaka}

Ahmed, Sara. 2010. Killing Joy: Feminism and the History of Happiness. Signs: Journal of Women in Culture and 
BIP: Jurnal Bahasa Indonesia Prima Vol. 3, No. 2, 2021, September 2021, PP.

Society, Vol. 35, No.3, hlm. 571593.

Carter, Angela. 1996. The Magic Toyshop. New Work: Penguin Books.

Creed, Barbara. 1993. The Monstrous Feminine: Film, Feminism, Psychoanalysis. New York: Routledge.

Delucia, Joellen. 2009. From the Female Gothic to a Feminist Theory of History: Ann Radcliffe and the Scottish Enlightenment. Journal The Eighteenth Century, Vol.50, No.1, hlm. 101-115.

Ellen, Moers. 1977. Literary Women. New York: Knopf Doubleday Publishing Group.

Falen dan Ara. 2020. Lasmi. Jakarta Selatan: Media Kita.
Fielding, Helen. 1996. Bridget Jones's Diary. New York: Penguin Books.

Hawkins, K. 2019. Monsters in the Attic: Women's Rage and the Gothic. Journal Media Culture, Vol.22, No.1, hlm. 1-7.

Hoeveler, Diana Long. 1998. Gothic Feminism: The Professionalization of Gender from Charlotte Smith to the Brontës. Pennsylvania: Penn State University Press.

Ledoux, Ellen. 2017. Was there ever a "Female Gothic"?. Journal Humanities and Social Sciences Communications, 01 Juni, hlm. 1-7.

Weldon, Fay. 1995. The Life and Loves of a She-Devil. New York: Trafalgar Square.

Wolf, Naomi. 1994. Fire with Fire: The New Female Power and How to Use It. New York: Ballantine Books. 